\title{
CTLA-4 and its role in autoimmune thyroid disease
}

\author{
D A Chistiakov and R I Turakulov ${ }^{1}$ \\ Laboratory of Aquatic Ecology, Katholieke Universiteit Leuven, B-3000 Leuven, Belgium \\ ${ }^{1}$ Centre for Bioinformatic Science, John Curtin School of Medical Research, ANU, Canberra GPO Box 334, ACT 2601, Australia \\ (Requests for offprints should be addressed to DA Chistiakov; Email: dimitry.chistyakov@ bio.kuleuven.ac.be)
}

\begin{abstract}
Autoimmune thyroid disease (AITD) occurs in two common forms: Graves' disease and Hashimoto thyroiditis. On the basis of functional and experimental data, it has been suggested that the gene encoding cytotoxic T-lymphocyte-associated antigen-4 (CTLA-4) is a candidate gene for conferring susceptibility to thyroid autoimmunity. In this review, we critically evaluate the evidence for pathogenetic involvement of CTLA-4 in the various forms of AITD and focus on the possible role of genetic variation of the CTLA4 locus. Population genetics data strongly suggest a role for the CTLA4 region in susceptibility to AITD. However, further functional studies are required to understand the significance of CTLA4 polymorphisms in the pathogenic mechanism of AITD.
\end{abstract}

Journal of Molecular Endocrinology (2003) 31, 21-36

\section{Introduction}

Autoimmune thyroid disease (AITD) is an organspecific disorder that affects the thyroid gland. It numbers among the most common human autoimmune diseases, affecting up to $5 \%$ of the general population (Wang \& Crapo 1997). To detect the clinical symptoms of AITD, thyroid volume is usually determined with ultrasonography, and serum concentrations of three hormones [thyrotrophin (TSH), thyroxine $\left(\mathrm{T}_{4}\right)$ and triiodothyronine $\left.\left(\mathrm{T}_{3}\right)\right]$ and autoantibodies against thyroid peroxidase (TPOab) and thyroglobulin (TGab) are measured.

Autoimmunity against the thyroid gland results in two opposite pathogenic paths: hyperthyroidism in Graves' disease and thyroid destruction in Hashimoto thyroiditis. Increased circulating activated $\mathrm{T}$ cells and thyroid-specific autoantibodies occur in Graves' disease. Antibodies directed against the TSH receptor stimulate thyroid function and lead to glandular overactivity (Kopp 2001). Depending on its severity, Graves' disease is classified as subclinical or overt hyperthyroidism. Subclinical hyperthyroidism is characterised by increased serum TSH concentrations (more than $5 \mathrm{mIU} / \mathrm{l})$ and normal $\mathrm{T}_{3}(1 \cdot 0-3 \cdot 0 \mathrm{nmol} / \mathrm{l})$ and $\mathrm{T}_{4}$ $(10-25 \mathrm{pmol} / \mathrm{l})$ estimates. The overt disease is determined by increased TSH and thyroid hormone values (Faber et al. 2001, Fatourechi 2001).

Hashimoto thyroiditis is characterised by the loss of thyroid cells and gradual destruction of the gland, leading to thyroid hormone deficiency (Eguchi 2001). Subclinical Hashimoto thyroiditis is determined by a reduced serum TSH concentration (less than $0.3 \mathrm{mIU} / \mathrm{ml}$ ) but with concentrations of free $\mathrm{T}_{3}$ and $\mathrm{T}_{4}$ hormones in the normal range. Under clinically presenting (overt) hypothyroidism, both TSH and thyroid hormone concentrations are decreased (Hueston 2001).

Postpartum thyroiditis is an autoimmune thyroid disorder affecting 5-9\% of women during the years after delivery. The disease shares immunological and clinical features with autoimmune hypothyroidism and Graves' disease, and seems to 
be caused by a combination of genetic and environmental factors (Lazarus et al. 2002). The immunological features of this disorder include the presence of TPOab (and, less commonly, TGab), abnormalities in the circulating $\mathrm{T}$ cell population and a goitre with lymphocytic infiltration, which are similar to the features of other forms of AITD (Stagnaro-Green 2000).

Extrathyroidal manifestations of AITD can affect the eyes and skin. Thyroid-associated ophthalmopathy (TAO) is clinically relevant in approximately $50 \%$ of patients with Graves' disease as Graves ophtalmopathy, but it may be found in patients with no past or present history of hyperthyroidism, or even in patients who are hypothyroid because of Hashimoto thyroiditis (Bartalena et al. 2000). Thyroid-associated ophthalmopathy is an inflammatory disease of the orbital tissues. The effects of inflammation, mediated through the release of cytokines, include proliferation of fibroblasts and adipocytes in the orbital soft tissues. The recruitment of $\mathrm{T}$ cells to the orbits of affected patients may result from the expression of the target of the aberrant immune response in Graves' disease - the TSH receptor - in the orbits of patients with these ophthalmic complications (Wiersinga \& Bartalena 2002).

Cytotoxic T-lymphocyte-associated antigen-4 (CTLA-4) has been shown to provide a negative signal to the $\mathrm{T}$ cell, thus limiting immune responses (Chambers \& Allison 1997). CTLA-4 controls the adaptation of $\mathrm{T}$ cells to a state of proliferative unresponsiveness and tolerance - a fate that is alternative to inducing productive immunity (Bugeon \& Dallman 2000). In addition, GTLA-4 signalling mediates antigen-specific apoptosis of $\mathrm{T}$ cells and suppresses autoreactive proliferation of $\mathrm{T}$ lymphocytes (Gribben et al. 1995). Therefore, this immunomodulatory protein is significant in regulating and maintaining self-tolerance. Breakdown of the tolerance may result in the induction of autoimmunity. T-lymphocyte-mediated destruction of host cells is one of the common pathogenic autoimmune mechanisms that include thyroid autoimmunity (Stassi \& De Maria 2002). CTLA-4 affects downregulation of $\mathrm{T}$ cell function and therefore may have a crucial role in T-cellmediated autoimmunity and hence in susceptibility to AITD (Karandikar et al. 1996).

In this review, we will discuss the role of CTLA-4 in thyroid autoimmunity. We will focus on the genetics of CTLA-4 and the possible role of genetic polymorphisms of the CTLA4 locus in predisposition to AITD.

\section{Structure of the CTLA4 gene and function of its protein product}

The human CTLA4 gene starts from $202949 \cdot 6 \mathrm{~kb}$ from the p-terminus of chromosome 2 and spans about $6 \cdot 2 \mathrm{~kb}$ on chromosome region $2 \mathrm{q} 33$ (Dariavach et al. 1988). It exists as a single copy per haploid genome and consists of four exons. The first exon encodes the leader sequence of 37 amino acids, the second an immunoglobulin (Ig) Vlike domain of 116 amino acids, the third a hydrophobic transmembrane region of 37 amino acids and the fourth a 34 amino acid cytoplasmic domain (Dariavach et al. 1988). Introns 1, 2 and 3 span $2 \cdot 5,0.5$ and $1 \cdot 1 \mathrm{~kb}$ respectively (Harper et al. 1991). The 5' region of the gene contains a Kozak consensus sequence with the ATG initiation codon, an in-frame stop codon $26 \mathrm{bp}$ upstream of this ATG and a TATA box 75 bp upstream of the stop codon (Harper et al. 1991). The 3' untranslated region (UTR) is about $1 \cdot 1 \mathrm{~kb}$ and comprises a stretch of almost 30 AT repeats (Harper et al. 1991). Two main human CTLA-4 transcripts of about 1.8 and $0.8 \mathrm{~kb}$ have been detected, the smaller of which may derive from the use of an alternate degenerated polyadenylation signal sequence (Harper et al. 1991).

The mature protein consists of 149 amino acids and is expressed exclusively in activated CD4(+) and CD8(+) T lymphocytes (Lindsten et al. 1993). However, an alternative splicing of the CTLA-4 mRNA has been described (Magistrelli et al. 1999). The alternative transcript has a deletion from nucleotide 456 (starting from the ATG codon) to nucleotide 563, resulting in the loss of exon 3 encoding 37 amino acids of the transmembrane domain and a frame-shift generating 22 extra amino acids before a translational termination at position 523 (Magistrelli et al. 1999). This spliced transcript produces a $23 \mathrm{kDa}$ soluble form of CTLA-4, as opposed to a $45 \mathrm{kDa}$ full-length transmembrane variant of the molecule (Oaks et al. 2000). Membrane CTLA-4 is expressed as a homodimer because of a disulphide bridge between cysteine residues at position 120 . The soluble form lacks this cysteine residue, existing as a monomer 
(Magistrelli et al. 1999). However, this CTLA-4 variant maintains the MUPPPY motif (critical for B7 molecule binding) and can therefore participate in the B7/CTLA-4/CD28 signalling pathway of T cell regulation. The soluble CTLA-4 is preferentially expressed in non-activated $\mathrm{T}$ cells (Oaks \& Hallett 2000). In rat tissues, both forms of CTLA-4 have been detected in lymph node, spleen and peripheral blood, only full-length CTLA-4 in adult thymus, only short CTLA-4 in bone marrow cells and neither form in non-lymphoid tissues (Oaks et al. 2000). The short splice variant of CTLA-4 was observed significantly more often in patients with AITD in comparison with non-affected individuals (Oaks \& Hallett 2000). This finding will be discussed below.

The human CTLA4 and CD28 genes are closely linked. They are separated by only $130 \mathrm{~kb}$ (Buonavista et al. 1992). CTLA-4 and CD28 are very similar at the message and gene structure levels. These homologies and gene proximity strongly suggest that CTLA-4 and CD28 are the direct products of a duplication event (Balzano et al. 1992). However, 3' and 5' flanking sequences of these genes have no homology, suggesting therefore that different regulatory mechanisms for the two genes might be functioning.

CTLA-4 and CD28 act as members of the same pathway of $\mathrm{T}$ cell regulation. The CTLA-4 molecule binds the same ligands as CD28 [B7-1 (CD80) and B7-2 (CD86)], but with at least a 10-fold greater affinity (Greene et al. 1996). CD28 is expressed both in resting and activated $\mathrm{T}$ cells (Leung \& Linsley 1994). Binding of the costimulatory B7 molecule to CD28 activates T cells and the immune response by inducing the expression of several cytokines, cytokine receptors and regulatory genes (Leung \& Linsley 1994). In contrast to CD28, CTLA-4 acts as negative regulator of $\mathrm{T}$ cell function and autoreactivity.

CTLA-4 can downregulate $\mathrm{T}$ cell responses by two separate mechanisms. One mechanism is CTLA-4-mediated negative signalling in response to $T$ cell receptor activation (Lee et al. 1998). This mechanism requires the cytoplasmic tail of CTLA-4 and can occur in early stages of an immune response when expression of CTLA-4 and B7 is limited (Carreno et al. 2000). The other mechanism operates through cell-surface competition between CTLA-4 and CD28 for B7 binding. This mechanism depends on the levels of surface expression of CTLA-4 (Carreno et al. 2000). Both mechanisms can occur in late stages of the immune response when there is increased expression of $\mathrm{B} 7$ and CTLA-4. Binding of B7 to CTLA-4 leads to termination of the immune response via limitation of CD28-mediated signalling, T cell anergy and T cell apoptosis (Perez et al. 1997, Oosterwegel et al. 1999). CTLA-4-deficient mice exhibit massive lymphoproliferative autoimmune disease (Tivol et al. 1995, Waterhouse et al. 1995). These observations suggest that the CTLA-4/B7 interaction has a key role in maintaining the peripheral immune tolerance status, and hence in autoimmunity (Tivol et al. 1996).

\section{Polymorphic markers within the CTLA4 gene}

The CTLA4 locus has three polymorphic markers, all of which have been examined in AITD. Firstly, there is a cytosine to thymine substitution at position $-318[\mathrm{C}(-318) \mathrm{T}]$ of the promoter region (Deichmann et al. 1996). This polymorphism can easily be detected by a polymerase chain reaction-restriction fragment length polymorphism (PCR-RFLP) approach using treatment with MseI restriction endonuclease (Deichmann et al. 1996). The $\mathrm{C}(-318) \mathrm{T}$ variation has a heterozygosity of approximately 0.25 and a polymorphism information content of $0 \cdot 15$.

The second nucleotide variation, an adenine to guanine transition, occurs at position $49(\mathrm{~A} 49 \mathrm{G})$ of exon 1 and leads to alanine to threonine amino acid substitution of codon 17 of the leader peptide (A17T) (Nistico et al. 1996). The AT17 dimorphism can be tested by a PCR-RFLP-based assay using BstEII restriction endonuclease (Marron et al. 1997). Heterozygosity is approximately 0.45 and it has a polymorphism information content of $0 \cdot 25$.

The third polymorphic marker is located in the 3' UTR of exon 4 (Harper et al. 1991). This (AT) $)_{n}$ dinucleotide repeat polymorphism starts at nucleotide 642 of exon 4 of the human CTLA4 gene (Dariavach et al. 1988). The marker is highly polymorphic: at least 23 different alleles containing from seven to 30 AT repeats can be detected by PCR (Polymeropoulos et al. 1991). The alleles are numbered in several ways: some authors have used mobility units based on automated fragment length analysis; others have estimated the length on the basis of the size of PCR products - $106 \mathrm{bp}, 108 \mathrm{bp}$, etc. Finally, some authors have used the number of 
A repeats. The $(\mathrm{AT})_{n}$ repeat dinucleotide marker is highly informative, with a heterozygosity of 0.93 and a polymorphism information content of 0.91 .

Strong linkage disequilibrium has been demonstrated between the promoter and exon 1 polymorphisms. In Germans, the $\mathrm{T}(-318)$ allele was strongly linked to the A49 allele (Donner et al. 1998), whereas a linkage of the allele $\mathrm{C}(-318)$ to the G49 allele was found in Koreans (Park et al. 2000). Evidence has been obtained for linkage between the G49 allele and the 106 bp allele of the $(\mathrm{AT})_{n}$ repeat polymorphism in some populations (Nistico et al. 1996, Larsen et al. 1999, Kouki et al. 2002).

The functional significance of the CTLA4 polymorphisms remains unclear. The $(\mathrm{AT})_{n}$ repeat may affect RNA stability; this ability has been demonstrated for AT-rich sequences in 3' UTRs of some genes (Shaw \& Kamen 1986). The dinucleotide polymorphism occurs in the vicinity of an intracellular localisation motif that is situated in the middle of exon 4 (Leung et al. 1995). Contained within this motif are a binding site and a phosphorylation signal for the $\mathrm{SH} 2$ domain containing tyrosine phosphatases (Leung et al. 1995). The T cell receptor and CTLA-4 both interact with this signal transduction pathway, but no studies relating these data to the CTLA4 polymorphisms are available at present.

In Swedish patients, a relationship between both the promoter and the exon 1 polymorphisms and the level of expression of CTLA-4 has been found (Ligers et al. 2001). A correlation between the codon 17 dimorphism and CTLA-4 mRNA levels has also been shown in peripheral lymphocytes from Canadian individuals (Barnes et al. 1997). However, no correlation between the A49 G dimorphism or the dinucleotide microsatellite and gene expression was observed in an other study (Cavallo et al. 1997). Meanwhile, recent studies have shown a relationship between the A49 G variation and the strength of downregulation of $\mathrm{T}$ cell activation (Kouki et al. 2000, Maurer et al. 2002). The exon 1 polymorphism was found to affect the inhibitory function of CTLA-4 and the G49 allele was associated with reduced control of T cell proliferation (Kouki et al. 2000). The intracellular distribution of CTLA-4 demonstrated qualitatively different staining patterns between patients with the $G / G$ genotype and individuals homozygous for A at position 49 (Maurer et al.
2002). These findings are extremely important to the understanding and assessment of a role for different molecular variants of CTLA-4 in the pathogenesis of thyroid and other autoimmune diseases.

\section{The CTLA4 gene and susceptibility of disease}

\section{The CTLA4 gene and susceptibility to Graves' disease}

The first evidence for association between the $(\mathrm{CA})_{n}$ dinucleotide repeat polymorphism at the $3^{\prime}$ UTR of the CTLA4 gene and Graves' disease in white North Americans was reported in 1995 (Yanagawa et al. 1995). Association of the three polymorphic markers of the CTLA4 gene with the disease was demonstrated in most population-based investigations (Table 1). The G49 allele of the codon 17 dimorphism has been shown to be a common genetic risk marker of Graves' disease in different populations. For the polymorphic $(\mathrm{CA})_{n}$ repeat, an association of the $106 \mathrm{bp}$ allele with a greater risk for the disease was detected in several studies (Kotsa et al. 1997, Hadj Kacem et al. 2001, Kouki et al. 2002). The CTLA4 locus is the only non-human leucocyte antigen (HLA) locus for which association with Graves' disease has been demonstrated repeatedly.

In 1999, a linkage to Graves' disease was also found using a set of 66 multiplex British families (Vaidya et al. 1999b). The CTLA4 locus located within a $10 \mathrm{cM}$ region of chromosome 2q31-q33 between markers D2S389 and D2S116 showed a maximum strength of linkage with the disorder (Vaidya et al. 1999b). The linkage of CTLA4 to Graves' disease was confirmed using an enlarged set of 179 UK families (Heward et al. 1999). However, family studies showed no linkage between the CTLA4 locus and Graves' disease in other populations (Maalej et al. 2001, Sakai et al. 2001, Nithiyananthan et al. 2002, Tomoyose et al. 2002, Villanueva et al. 2002). It thus remains questionable whether the CTLA4 gene is linked to the disease.

Without doubt CTLA4 is strongly associated with Graves' disease. In white Britons, the CTLA4 locus and the HLA locus together confer up to $50 \%$ of the inherited susceptibility to the disease (Vaidya 

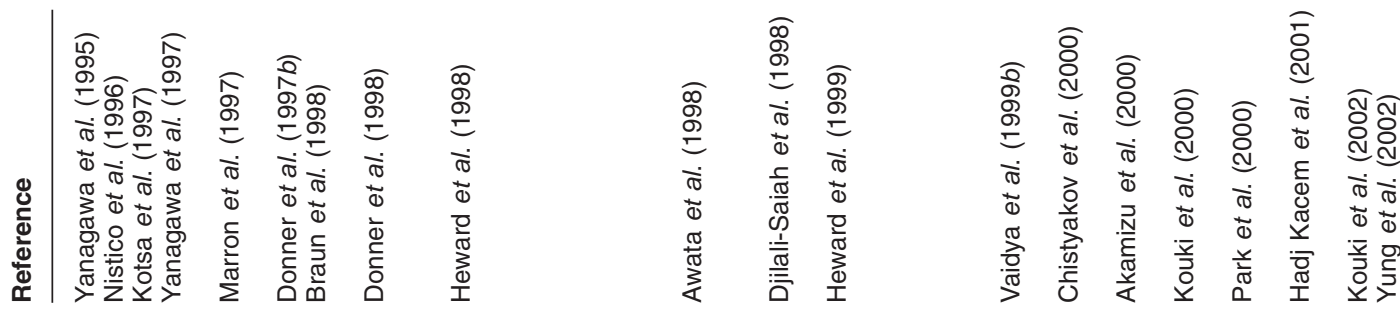

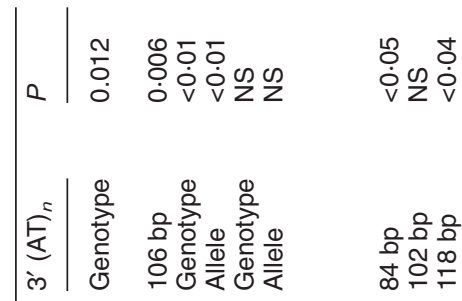

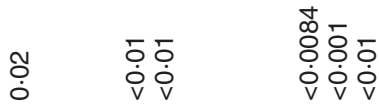

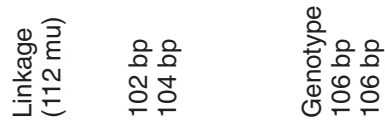

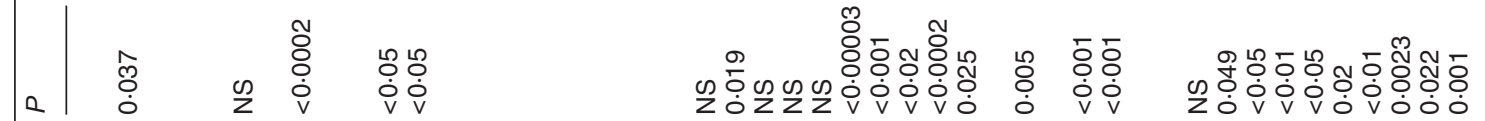

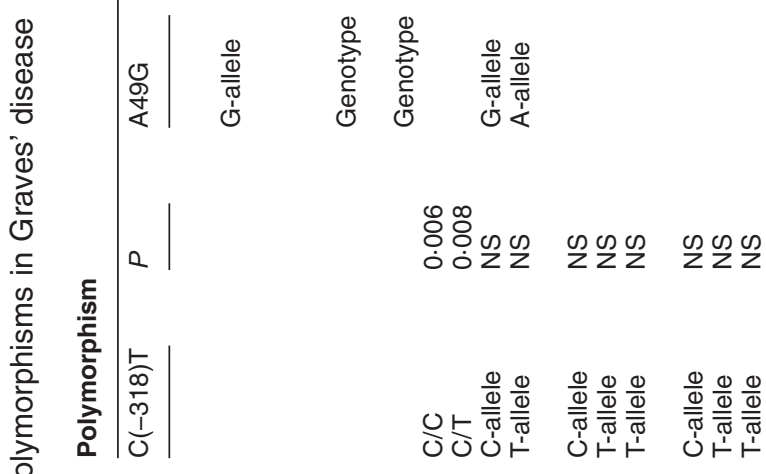

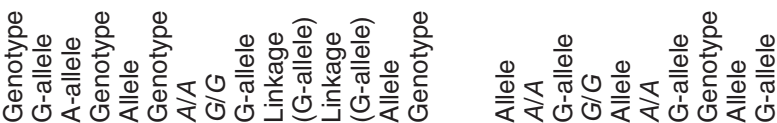

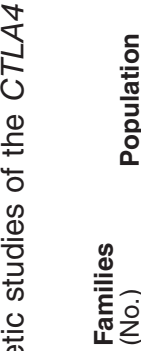

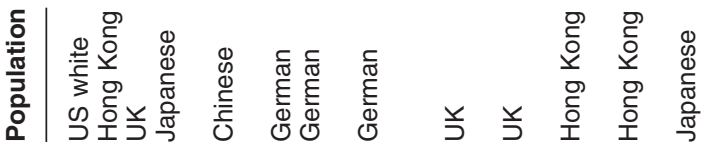

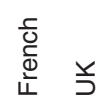

늉ㅇํㅇ

ì
焉

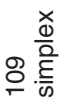

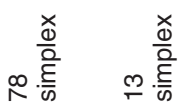

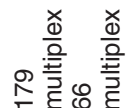

仓)

它官|

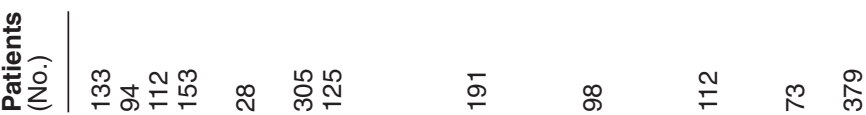

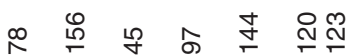

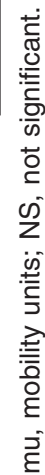


et al. 1999b). The region of linkage to Graves' disease on chromosome 2q31-q33 is close to a locus of susceptibility to insulin-dependent diabetes mellitus (IDDM), IDDM12 (Vaidya et al. 1999b). CTLA4 is the most likely known candidate gene for IDDM12 on 2q33 (Nistico et al. 1996, Marron et al. 1997, She \& Marron 1998). Besides the association of the CTLA4 locus with IDDM and Graves' disease, relationships between this locus and other autoimmune diseases such as multiple sclerosis, Addison's disease, rheumatoid arthritis and systemic lupus erythematosus have been demonstrated (Kristiansen et al. 2000). Thus the CTLA4 locus might be established as the first known major non-HLA locus of human autoimmunity.

\section{The CTLA4 gene and susceptibility to Hashimoto thyroiditis}

A significant association between the CTLA4 gene and Graves' disease has been found in several populations. In contrast, there are few studies that have examined whether this gene is associated with Hashimoto thyroiditis (Table 2). Kotsa et al. (1997) reported that the dinucleotide microsatellite of the CTLA4 gene is associated with autoimmune hypothyroidism in the British population. Other investigators have obtained evidence of association with the disease for the $(\mathrm{AT})_{n}$ repeat polymorphism (Sale et al. 1997) and the codon 17 dimorphic site (Donner et al. 1997a, Awata et al. 1998, Barbesino et al. 1998, Tomer et al. 1999), but never for the $\mathrm{C}(-318) \mathrm{T}$ substitution in the promoter region of the CTLA4 gene (Braun et al. 1998, Heward et al. 1998, Tomer et al. 1999, Park et al. 2000, Tomoyose et al. 2002). In the case of Graves' disease, an association has been demonstrated for all three polymorphisms. However, too few data are available to permit the conclusion that the promoter polymorphism is not associated with Hashimoto thyroiditis. Further population studies are required to determine whether this single nucleotide polymorphism is related to the disorder.

Analysis of 48 multiplex families, of which 46 were white, 20 had at least two members with Hashimoto thyroiditis and 17 had one sibling affected by Hashimoto thyroiditis, showed no linkage between the CTLA4 (AT) $)_{n}$ repeat polymorphism and autoimmune hypothyroidism (Nithiyananthan et al. 2002). A whole-genome scan using a subset of 42 families (22 comprising only Hashimoto thyroiditis-affected members, and 20 with one child affected by Hashimoto thyroiditis) from 56 white multiplex AITD families mapped three regions of linkage with autoimmune hypothyroidism on chromosome 6p (AITD-1 susceptibility locus), 12q22 [Hashimoto thyroiditis (HT)-1 locus] and 13q22 (HT-2 locus), and showed no linkage to chromosome 2q33, where the CTLA4 gene is located (Tomer et al. 1999). A recent genome-wide analysis using data from 123 Japanese sib-pairs affected with AITD found a new Hashimoto thyroiditis susceptibility locus at chromosome 8q23-q24, but not at 2q33 (Sakai et al. 2001). These data thus suggest that the CTLA4 gene is probably not linked to Hashimoto thyroiditis. However, there seems to be some evidence supporting an association between the CTLA4 locus and Hashimoto thyroiditis.

\section{The CTLA4 gene and susceptibility to autoimmune thyroid disease}

Case--control studies on the association between the CTLA4 gene and AITD have been performed in Japan only, and their results are conflicting (Sale et al. 1997, Akamizu et al. 2000). No evidence was found for linkage between the CTLA4 gene and AITD (Nithiyananthan et al. 2002) in studies that included two genome-wide scans (Tomer et al. 1999, Sakai et al. 2001) and analyses of large Tunisian (Maalej et al. 2001) and Chinese pedigrees (Villanueva et al. 2002).

Meanwhile, a number of investigations support a relation between the CTLA4 gene and features of autoimmune thyroid disease such as production of thyroid autoantibody (Tab). The G49 allele was found to be associated with greater concentrations of $\mathrm{Tab}$ and to be linked to Tab production, including production of TGab and TPOab (Tomer et al. 2001, Zaletel et al. 2002). A susceptibility locus for Tab production was mapped on chromosome 2q33 around marker D2S155, which is linked to the region containing the CTLA4 and CD28 genes (Tomer et al. 2001). Further analysis showed that a major gene for production of $\mathrm{Tab}$ on chromosome 2q33 is most probably the CTLA4 gene and not the CD28 gene (Tomer et al. 2001). However, there was still no evidence that CTLA4 contributes specifically to Graves' or Hashimoto diseases. 

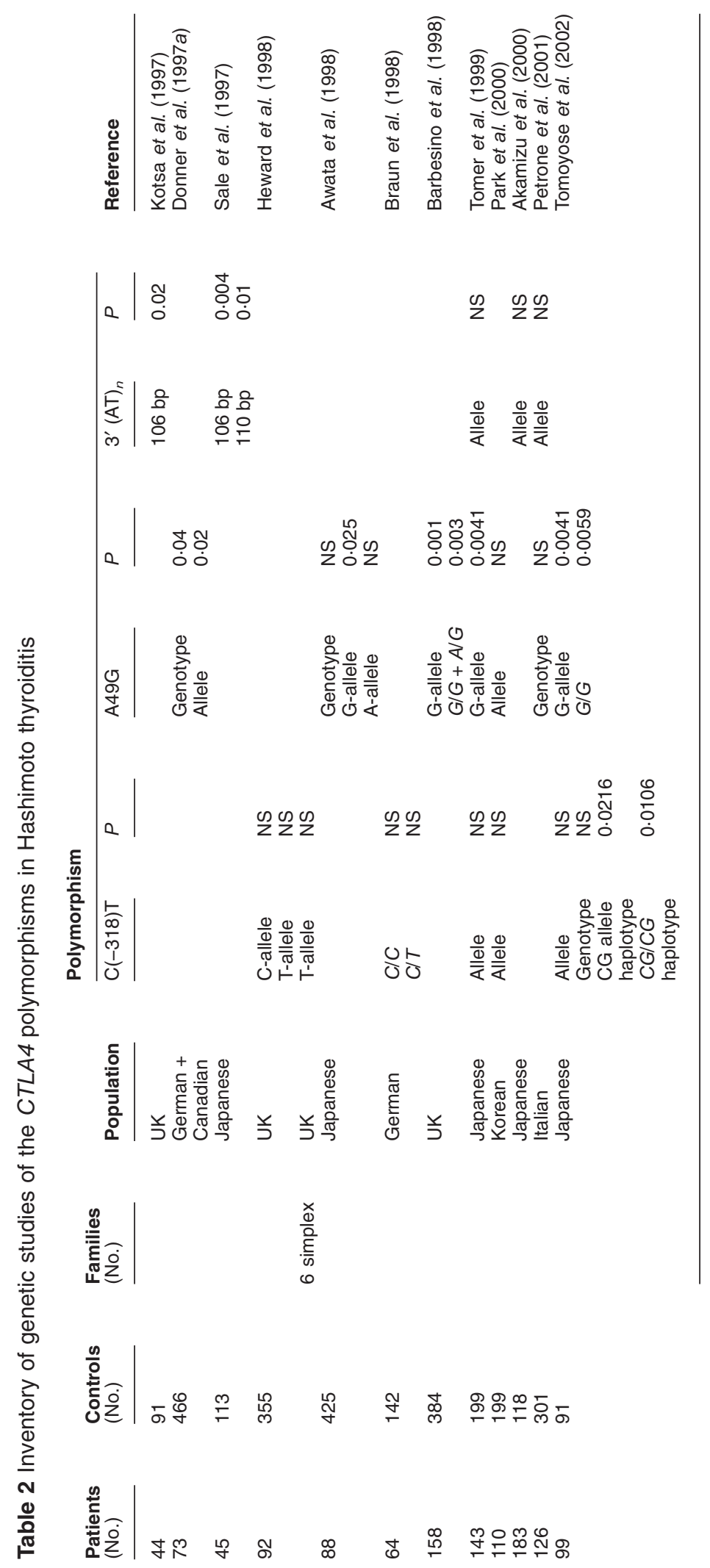

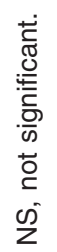




\section{The CTLA4 gene and susceptibility to other forms of autoimmune thyroid disease}

The codon 17 dimorphism of the CTLA4 gene has been tested for association with thyroid-associated ophthalmopathy. Buzzetti et al. (1999) and Vaidya et al. (1999b) found an association of the G49 allele with increased risk of Graves' disease in white patients in the UK and Italy respectively, whereas the findings of other case-control studies were negative (Table 3). For polymorphisms of other immune response genes, conflicting results have been reported (Farid \& Balasz 1998, Buzetti et al. 1999, Hunt et al. 2000). The segregation ratio for ophthalmopathy in families with Graves' disease was shown to be zero, suggesting that environmental factors rather than genetic factors predispose to the development of this ophthalmopathy (Villanueva et al. 2000, Bednarczuk et al. 2003). Therefore, the CTLA4 polymorphism is probably not associated with thyroid-associated ophthalmopathy. However, Vaidya et al. (1999b) showed a maximum association strength of the G49 allele (odds ratio 3.06) with severe forms of the disease, suggesting that genetic factors could contribute more significantly to the severity of thyroidassociated ophthalmopathy.

One investigation concerned the association of the CTLA4 gene with postpartum thyroiditis only. No significant association between the $106 \mathrm{bp}$ allele of the polymorphic (AT) ${ }_{n}$ repeat (which is in linkage disequilibrium with the G49 allele) and the disease was observed in the Welsh population (Waterman et al. 1998). More studies are therefore required for estimating the genetic role of the CTLA4 locus in the aetiology of postpartum thyroiditis.

\section{Possible reasons for the inconsistencies between disease states and CTLA4 genotype}

Among the different forms of AITD, the polymorphisms of the CTLA4 gene showed strong association with Graves' disease, demonstrated conflicting findings in Hashimoto thyroiditis patients and rather a lack of association with thyroid-associated ophthalmopathy. Difference in definition of the disease is one factor that can cause the discrepancies between case-control studies. Variability in the normal range of $\mathrm{TSH}$ and thyroid hormone concentrations is not very marked between different investigations, but significant dispersal occurs in AITD-defined estimates of serum anti-thyroid autoantibodies (50-200 U/ml for TGab, 10-60 U/ml for TPOab and 9-15 U/1 for antibodies against the TSH receptor).

Another possible reason for inconsistencies between disease states and CTLA4 genotype may lie in significant variations in the ratio of women to men in the case groups tested (from 2.5 to 14.8 ) compared with the controls (from 0.9 to $3 \cdot 5$ ).

The codon 17 amino acid substitution has been shown to be functionally relevant (Maurer et al. 2002) and has been tested significantly more often than the two other CTLA4 polymorphisms. It seems that the A49 G dimorphism allele frequencies do not change significantly in relation to age and sex, but can vary markedly in relation to ethnic background: the A49 allele dominates in whites, whereas the G49 allele is most common in Asian populations (Yung et al. 2002). However, patients in almost all case-control studies were ethnically matched and an association with the disease was observed in both whites and Asians. Ethnic and regional heterogeneity may therefore contribute weakly to explaining the differences between association studies.

Using equations reported by Ohashi et al. (2001) and Tsuchiya et al. (2002), it is possible to estimate the number of cases needed to obtain a statistical power of $1-\beta$ with a significance level of $\alpha$. We can take two extreme examples, based on the size of the sample tested. Heward et al. (1999) showed a significant association between the A49 G dimorphic site of the CTLA4 gene and Graves' disease $(P<0 \cdot 00003)$, studying 379 affected patients and 363 controls. For this study, at least 151 cases are required to obtain $80 \%$ power with a significance level of 0.05 in a two-sided test; Heward's group studied a case sample $2 \cdot 5$ times larger than this. In contrast, Kouki et al. (2000) analysed only 45 patients with Graves' disease and 43 healthy individuals; nevertheless they also found an association. In their study, at least 46 affected individuals should have been examined to achieve the significance level mentioned above. Thus the association found by Kouki et al. (2000) is questionable rather than true. Other investigators have analysed samples of sizes intermediate between these extreme examples, which should be adequate to reveal significant associations.

However, finding an association does not always mean finding a susceptibility gene. Most of the 

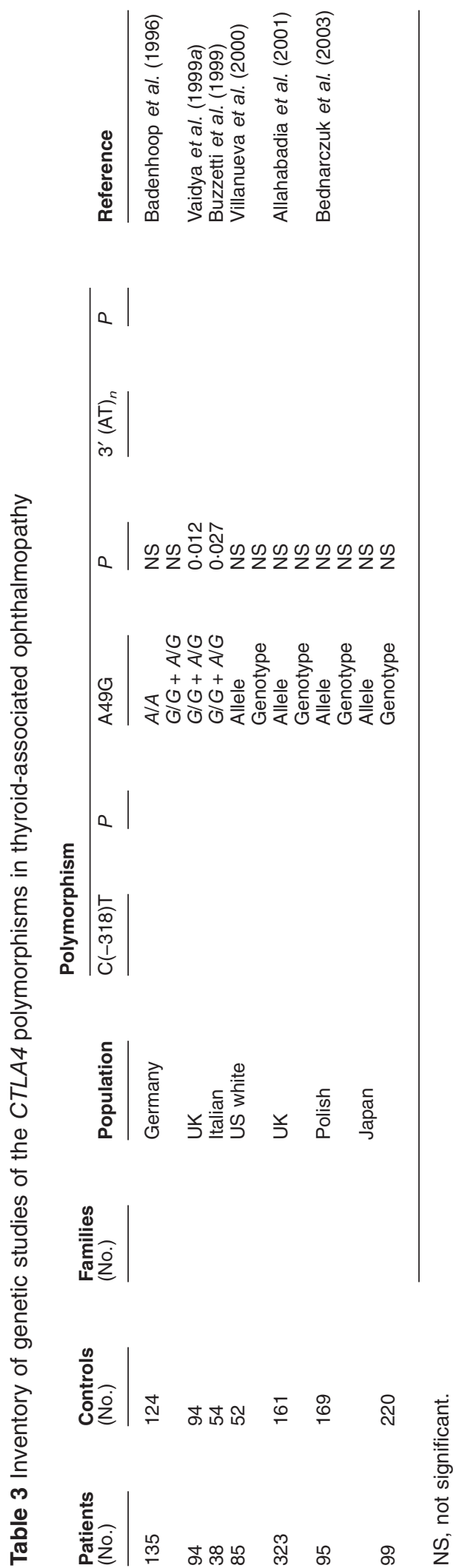
susceptibility genes with genotype relative risks greater than $2 \cdot 0$ and a frequency of the disease allele of more than 0.2 can be identified with a power of 0.8 using about 500 cases and 500 controls (Ohashi et al. 2001). If the sample size for each group is about 100 and the frequency ranges between $0 \cdot 1$ and $0 \cdot 4$, a genotype relative risk of more than 3.0 is required to detect the susceptibility gene with $80 \%$ statistical power. For the $G / G$ homozygous genotype, a relative risk value ranging between $2 \cdot 0$ and $2 \cdot 8$ was obtained in most case-control studies using the A49 G polymorphism to detect association between the CTLA4 gene and thyroid autoimmunity. Thus it remains unclear whether the CTLA4 gene is a true AITD susceptibility gene or whether the polymorphisms within this gene are in strong linkage disequilibrium with a nearby gene that implicates susceptibility to AITD.

\section{Functional significance of the CTLA4 gene polymorphisms and their possible applications in the pathogenesis of thyroid autoimmunity}

\section{Role of CTLA-4 in the pathogenic mechanism of autoimmune thyroid disease}

Among all three known polymorphic markers of the CTLA4 gene, a functional significance is only more or less clear for the codon 17 polymorphism. Because of the relationship of the G49 allele to a greater risk for AITD, $G / G$ homozygous patients might be expected to have a weak suppressing function of the Ala17 molecular variant of CTLA-4 in comparison with the $A / A$ genotype. Disruption of the precise balance between CD28 and CTLA-4 interactions with B7 could lead to autoimmune disease by preventing apoptosis or downregulation of activated $T$ cells (Tivol et al. 1996). Hence, aberrant $\mathrm{T}$ cell clones can survive in the thymus and produce autoantibodies against the TSH receptor and other thyroid autoantigens that could initiate autoimmune thyroid disease (Shimojo et al. 1996). This idea is supported by the data of Kouki et al. (2000), who found that the G49 allele is associated with reduced control of $\mathrm{T}$ lymphocyte proliferation.

Recent findings suggest that levels of surface expression of CTLA-4 and its intracellular distribution correlate with a genotype at position 49
(Maurer et al. 2002). Individuals carrying the $G / G$ genotype had reduced upregulation of surface expression of CTLA-4, whereas activated T cells from patients homozygous for adenine revealed a more circular and homogeneous cytoplasmic pattern of staining for CTLA-4 localisation compared with that in $G / G$ homozygotes (Maurer et al. 2002). A relationship between the genotype and level of expression of CTLA-4 was demonstrated in other recent investigations (Ligers et al. 2001). Specifically, individuals carrying thymine at position -318 of the CTLA4 promoter and homozygous for adenine at position 49 in exon 1 showed significantly increased expression both of cell-surface CTLA-4 after cellular stimulation and of CTLA-4 mRNA in non-stimulated cells (Ligers et al. 2001).

The majority of CTLA-4 molecules occur within the cytoplasm and can be quickly mobilised from intracellular store compartments to the site of $\mathrm{T}$ cell receptor engagement on the cell surface (Linsley et al. 1996). Hence, low concentrations of intracellular CTLA-4 may correlate with decreased cell surface expression of CTLA-4 and therefore with reduced negative control of $\mathrm{T}$ cell proliferation. The CTLA4 A49 G single nucleotide polymorphism results in the substitution of threonine with alanine at codon 17 of the leader sequence. This sequence serves as a signal peptide to direct the secreted protein to the endoplasmic reticulum. The codon 17 amino acid variation can affect a conformation of the leader peptide that leads to an 'altered address' of intracellular CTLA-4 trafficking. This might result in altered transition of CTLA-4 molecules between intracellular pools and the cell surface. So, carriers of the Ala1 7 molecular variant of CTLA-4 should exhibit less effective transition of intracellular CTLA-4 to the $\mathrm{T}$ cell surface (Simon \& Blobel 1991). This might correlate with decreased negative regulation of $\mathrm{T}$ cell proliferation and therefore predispose to greater risk of development of AITD.

However, Xu et al. (2002) showed that there was no differential effect of the A49 and G49 alleles on the expression and function of recombinant human CTLA-4 in vitro. Hence, these data mean that the functional relevance of the codon 17 polymorphism remains questionable and suggest that cell membrane CTLA-4 may be not directly involved in the pathogenesis of autoimmune disease. Meanwhile, the A49 G substitution has been shown to be in 
linkage disequilibrium with other polymorphic sites within the CTLA4 gene that can be functionally significant (Donner et al. 1998, Park et al. 2000, Kouki et al. 2002).

Some interesting investigations were carried out to clarify the functional relevance of these polymorphic sites. It has been shown that the presence of thymine at position -318 of the CTLA4 promoter and adenine at position 49 in exon 1 is significantly correlated with greater expression, both of cell-surface CTLA-4 after cellular stimulation and of CTLA-4 mRNA in non-stimulated $\mathrm{T}$ cells (Ligers et al. 2001). Enlarging the length of the $3^{\prime}$ UTR $(\mathrm{AT})_{n}$ microsatellite of the allele has been observed to correlate with $\mathrm{T}$ cell hyperactivity in vitro and can result in increased instability of CTLA-4 mRNA (Huang et al. 2000). Further functional genomics studies are required to derive an in-depth understanding of the significance both of the $\mathrm{C}(-318) \mathrm{T}$ promoter and the 3' UTR dinucleotide polymorphism in the molecular mechanism of autoimmunity.

Another possibility may lie in the alternately spliced form of CTLA-4 (Magistrelli et al. 1999, Giorelli et al. 2001). In contrast to the full-length membrane CTLA-4, this molecular variant of CTLA-4 (soluble CTLA-4, or sCTLA-4) lacks the transmembrane domain and can be constitutively expressed by non-activated $\mathrm{T}$ cells (Oaks et al. 2000). The sCTLA-4 is found to be significantly more frequent in patients affected with autoimmune thyroid disease than in healthy individuals (Oaks \& Hallett 2000). A role of this CTLA-4 form in AITD is unknown and is being predicted only. The soluble CTLA-4 has a B7 recognition site and therefore can successfully compete with the membrane CTLA-4 for B7 binding. Increased concentrations of sCTLA-4 could impede the full-length CTLA-4 from performing its protective role against autoimmune reactive $\mathrm{T}$ cell clones and from contributing in this way to the development of thyroid autoimmune pathology. In this regard, it is interesting that the sCTLA-4 does not appear to be expressed within the thymus, an organ in which negative selection of autoreactive $\mathrm{T}$ lymphocytes occurs (Oaks et al. 2000).

Finally, there are several possible mechanisms for CTLA-4-directed genetic effects in the modulation of the development of AITD. Two or more polymorphisms of the CTLA4 gene might be responsible for this modulation and these polymorphisms may cosegregate in a common risk haplotype (Tomer 2001).

\section{How many genes in the CTLA4 region can predispose to the autoimmune thyroid disease?}

Population genetic data clearly suggest a role for the CTLA4 region in susceptibility to AITD: we have strong evidence for the association between the CTLA4 gene and thyroid autoimmunity. Nevertheless, it remains unclear whether the CTLA4 locus is linked to the disease, because linkage between the CTLA4 gene and Graves' disease has been demonstrated in the British population only (Heward et al. 1999, Vaidya et al. 1999b).

AITD seems to be a polygenic disease with no major susceptibility locus. The CTLA4 gene has been shown to be a susceptibility factor that is separate from the HLA locus in Graves' disease and Hashimoto thyroiditis (Yanagawa et al. 1995, Donner et al. 1997a,b). The CTLA4 region and the $H L A$ locus have been established as the loci that predispose to AITD, and each of them has a minor but significant effect (Tomer \& Davies 1997). Using non-parametric linkage analysis provides a genome-wide search for the susceptibility regions, but has low power of detection to identify loci with relatively small genetic effects, whereas casecontrol association studies have strong advantages for the detection of such loci (Tsuchiya et al. 2002). All previous whole-genome scans searching for the loci of AITD susceptibility dealt with family sets of relatively small numbers (Tomer et al. 1999, Sakai et al. 2001). It would be necessary to enlarge the data set significantly in order to have sufficient power to reveal linkage between the disease and genomic regions with minor genetic effects.

The G49 CTLA4 allele has been found to be associated with greater levels of thyroid antibodies and to be linked to Tab production, including production of TGab and TPOab (Tomer et al. 2001, Zaletel et al. 2002). Hence, CTLA4 might be the susceptibility gene for thyroid autoantibody production, and the G49 allele may predispose individuals to develop Tab. Alternatively, the CTLA4 codon 17 polymorphism might be in strong linkage disequilibrium with another causative gene 
that implicates susceptibility to Tab production. It does not exclude the possibility that there are two closely linked genes (one of them likely to be CTLA4) accounting for the susceptibility to produce autoantibodies against the thyroid.

The CTLA4 gene is located in a chromosome region $2 q 33$ that contains the genes encoding two other T lymphocyte costimulatory receptors, CD28 and ICOS (Ling et al. 2001). The CD28 gene has been excluded as the putative susceptibility gene in this region (Marron et al. 2000, Tomer et al. 2001). The ICOS gene might be a likely candidate for Tab production; it encodes an inducible $\mathrm{T}$ cell costimulator and is separated from the CTLA4 gene by $69 \mathrm{~kb}$ (Coyle et al. 2000, Ling et al. 2001).

The ICOS gene is a member of the family of CD28 and CTLA-4 cell-surface receptors and shares 24\% and $17 \%$ identity with the CD28 and CTLA-4 amino acid sequences respectively (Hutloff et al. 1999). ICOS matches CD28 in potency and enhances all basic $\mathrm{T}$ cell responses to a foreign antigen - namely proliferation, secretion of lymphokines, upregulation of molecules that mediate cell-cell interaction, and effective help for antibody secretion by B cells (Dong et al. 2001). The ICOS gene is closely linked to the CTLA4 gene and therefore might interfere with the contribution of CTLA4 to susceptibility to thyroid antibody production.

It has recently been found that CTLA-4 is able to inhibit ICOS-mediated costimulation and prevent ICOS-costimulated T cells from producing interleukins-4, -10 and -13 (Riley et al. 2001). This suggests an alternative mechanism of CTLA-4 function, disruption of which could also predispose to autoimmunity. Therefore, the ICOS gene might be considered to be another candidate for susceptibility gene of thyroid autoimmunity. Some polymorphisms have been detected in non-coding regions of the ICOS gene (Haimila et al. 2002, Ling et al. 2001). One of these polymorphisms, the dinucleotide microsatellite located in intron 4, was tested but showed no association with autoimmune diabetes in a Japanese population (Ihara et al. 2001). More genetic and functional studies of ICOS are needed to identify clearly its role in autoimmunity.

Other possible candidates may be found among members of the CFLAR-CASP10-CASPO gene cluster that is positioned about $2.7 \mathrm{Mb}$ distal to the CD28-CTLA4-ICOS gene cluster (Grenet et al.
1999). This cluster encodes caspase 8 and FADD-like apoptosis regulator (CFLAR) and caspases 8 and 10. Both caspases have shown to be involved in CD95-mediated cell apoptosis (Sprick et al. 2002). Interactions between CD95 and its ligand mediate thyrocyte destruction in Hashimoto thyroiditis (Stassi et al. 2000, Eguchi 2001). Caspases and death receptors/ligands would appear to play a part in CD95-induced apoptosis of Hashimoto thyroiditis thyrocytes (Hammond et al. 2001, Stassi \& De Maria 2002). In addition, mutations in the CASP10 gene lead to breakdown of lymphocyte homeostasis and normal immunological tolerance, and lead to the development of autoimmune lymphoproliferative syndrome (Jackson \& Puck 1999). These findings favour the caspase-encoding genes as candidates for thyroid autoimmunity susceptibility gene(s).

\section{Conclusions}

CTLA4 as a thyroid autoimmunity susceptibility gene cannot explain the full genetic susceptibility to AITD. This gene has a significant but relatively small effect, and does not seem to determine the phenotypic expression of thyroid autoimmunity such as Graves' disease, Hashimoto thyroiditis and production of Tabs (Tomer 2001).

AITD can often occur in conjunction with other autoimmune disorders (IDDM, vitiligo, multiple sclerosis, Addison's disease, rheumatoid arthritis, systemic lupus erythematosus and others). Familial association studies have also reported an increased risk of several systemic autoimmune diseases among relatives of patients with a systemic autoimmune disease. This association may reflect a common aetiological pathway with shared genetic or environmental influences among these diseases (Cooper et al. 1999, Devendra \& Eisenbarth 2003). There is also evidence that many autoimmune diseases share a common set of susceptibility genes.

In the case of CTLA4 gene polymorphisms, an association has been observed with several autoimmune disorders (Kristiansen et al. 2000). CTLA-4 controls common immunity traits such as the amplitude of the immune response and peripheral tolerance, disruption of which can cause autoimmune disease. Hence, the CTLA4 gene contributes to autoimmunity in general, but cannot account for determining the organ-specificity of 
autoimmunity, and its role in the predisposition to AITD is rather non-specific (Rapoport \& McLachlan 2001, Einarsdottir et al. 2003, Weetman 2003).

Genetic susceptibility factors in familial forms of complex diseases such as AITD and IDDM may be constituted by the combined effect of minor risk factors, accumulating in a greater-risk haplotype. Therefore, susceptibility loci with low genetic effects (such as CTLA4) could be successfully identified through genetic analysis of large pedigrees (Einarsdottir et al. 2003).

Further genetic and functional experiments should be undertaken to estimate the significance of the CTLA4 gene in thyroid autoimmunity. In this respect, the use of animal models would help to increase the power of linkage analysis to locate susceptibility genes with minor effects, because of the complete nature of the information to be derived from all matings (all parents are heterozygous in an intercross) and the reduction of genetic complexity in inbred strains (Lam-Tse et al. 2002). Secondly, animals affected by autoimmune diseases provide a unique opportunity for a precise understanding of the early stages of the endocrine autoimmune process and the identification of disease-associated pathways, which are complicated to define in man. Thirdly, animal models are extremely helpful for testing and studying the treatment effects of CTLA4-Ig, a new immunosuppressive therapeutic agent that is more and more widely used for inhibition of T-cell-dependent antibody responses to slow progression of autoimmune disease, to induce long-term donor-specific tolerance and to prolong the survival of transplanted organ in recipient patients (Najafian \& Sayegh 2000).

\section{References}

Akamizu T, Sale MM, Rich SS, Hiratani H, Noh JY, Kanamoto N, Saijo M, Miyamoto Y, Saito Y, Nakao K \& Bowden DW 2000 Association of autoimmune thyroid disease with microsatellite markers for the thyrotropin receptor gene and CTLA-4 in Japanese patients. Thyroid 10 851-858.

Allahabadia A, Heward JM, Nithiyananthan R, Gibson SM, Reuser TT, Dodson PM, Franklyn JA \& Gough SC 2001 MHC class II region, CTLA4 gene, and ophthalmopathy in patients with Graves' disease. Lancet 358 984-985.

Awata T, Kurihara S, Iitaka M, Takei S, Inoue I, Ishii C, Negishi K, Izumida T, Yoshida Y, Hagura R, Kuzuya N, Kanazawa Y \& Katayama S 1998 Association of CTLA-4 gene A-G polymorphism (IDDM12 locus) with acute-onset and insulin-depleted IDDM as well as autoimmune thyroid disease
(Graves' disease and Hashimoto's thyroiditis) in the Japanese population. Diabetes 47 128-129.

Badenhoop K, Donner H, Braun J, Siegmund T, Rau H \& Usadel KH 1996 Genetic markers in diagnosis and prediction of relapse in Graves' disease. Experimental and Clinical Endocrinology and Diabetes. Supplement $4 \mathbf{1 0 4}$ 98-100.

Balzano C, Buonavista N, Rouvier E \& Golstein P 1992 CTLA-4 and CD28: similar proteins, neighbouring genes. International Journal of Cancer. Supplement 7 28-32.

Barbesino G, Tomer Y, Concepcion E, Davies TF \& Greenberg DA. 1998 Linkage analysis of candidate genes in autoimmune thyroid disease: 1 . Selected immunoregulatory genes. International Consortium for the Genetics of Autoimmune Thyroid Disease. Journal of Clinical Endocrinology and Metabolism 83 1580-1584.

Barnes R, Grabs R \& Polychronakos C 1997 A CTLA4 polymorphism affects lymphocyte mRNA levels but is not associated with type 1 diabetes mellitus in Canadian dataset. Diabetologia 40194.

Bartalena L, Pinchera A \& Marcocci C 2000 Management of Graves' ophthalmopathy: reality and perspectives. Endocrine Reviews 21 168-199.

Bednarczuk T, Hiromatsu Y, Fukutani T, Jazdzewski K, Miskiewicz P, Osikowska M \& Nauman J 2003 Association of cytotoxic T-lymphocyte-associated antigen-4 (CTLA-4) gene polymorphism and non-genetic factors with Graves' ophthalmopathy in European and Japanese populations. European Fournal of Endocrinology 148 13-18.

Braun J, Donner H, Siegmund T, Walfish PG, Usadel KH \& Badenhoop K 1998 CTLA-4 promoter variants in patients with Graves' disease and Hashimoto's thyroiditis. Tissue Antigens $\mathbf{5 1}$ 563-566.

Bugeon L \& Dallman MJ 2000 Costimulation of T cells. American Fournal of Respiratory and Critical Care Medicine 162 S164-S168.

Buonavista N, Balzano C, Pontarotti P, Le Paslier D \& Golstein P 1992 Molecular linkage of the human CTLA4 and CD28 Ig-superfamily genes in yeast artificial chromosomes. Genomics $\mathbf{1 3}$ 856-861.

Buzzetti R, Nistico L, Signore A \& Cascino I 1999 CTLA-4 and HLA gene susceptibility to thyroid-associated orbitopathy. Lancet 3541824.

Carreno M, Bennett F, Chau TA, Ling V, Luxenberg D, Jussif J, Baroja ML \& Madrenas J 2000 CTLA-4 (CD152) can inhibit T cell activation by two different mechanisms depending on its level of cell surface expression. Fournal of Immunology 165 1352-1356.

Cavallo MG, Leytze G \& Buzzetti R 1997 Study of CTLA-4 gene expression in patients with IDDM. Diabetes 461319.

Chambers CA \& Allison JP 1997 Co-stimulation in T cell responses. Current Opinion in Immunology 9 396-404.

Chistiakov DA, Savost'anov KV, Turakulov RI, Petunina NA, Trukhina LV, Kudinova AV, Balabolkin MI \& Nosikov VV 2000 Complex association analysis of Graves disease using a set of polymorphic markers. Molecular Genetics and Metabolism 70 214-218.

Cooper GS, Miller FW \& Pandey JP 1999 The role of genetic factors in autoimmune disease: implications for environmental research. Environmental Health Perspectives 107 693-700.

Coyle AJ, Lehar S, Lloyd C, Tian J, Delaney T, Manning S, Nguyen T, Burwell T, Schneider H, Gonzalo JA, Gosselin M, Owen LR, Rudd CE \& Gutierrez-Ramos JC 2000 The CD28-related molecule ICOS is required for effective T cell-dependent immune responses. Immunity 13 95-105.

Dariavach P, Mattei MG, Golstein P \& Lefranc MP 1988 Human Ig superfamily CTLA-4 gene: chromosomal localization and identity of protein sequence between murine and human CTLA-4 cytoplasmic domains. European Fournal of Immunology 18 1901-1905.

Deichmann K, Heinzmann A, Bruggenolte E, Forster J \& Kuehr J 1996 An Mse I RFLP in the human CTLA4 promoter. Biochemical and Biophysical Research Communications 225 817-818. 
Devendra D \& Eisenbarth GS 2003 Immunologic endocrine disorders. Fournal of Allergy and Clinical Immunology 111624636.

Djilali-Saiah I, Larger E, Harfouch-Hammoud E, Timsit J, Clerc J, Bertin E, Assan R, Boitard C, Bach JF \& Caillat-Zucman S 1998 No major role for the CTLA-4 gene in the association of autoimmune thyroid disease with IDDM. Diabetes 47 125-127.

Dong C, Juedes AE, Temann UA, Shresta S, Allison JP, Ruddle NH \& Flavell RA 2001 ICOS co-stimulatory receptor is essential for T-cell activation and function. Nature 409 97-101.

Donner H, Braun J, Seidl C, Rau H, Finke R, Ventz M, Walfish PG, Usadel KH \& Badenhoop K $1997 a$ Codon 17 polymorphism of the cytotoxic T lymphocyte antigen 4 gene in Hashimoto's thyroiditis and Addison's disease. Foumal of Clinical Endocrinology and Metabolism 82 4130-4132.

Donner H, Rau H, Walfish PG, Braun J, Siegmund T, Finke R, Herwig J, Usadel KH \& Badenhoop K 1997b CTLA4 alanine-17 confers genetic susceptibility to Graves' disease and to type 1 diabetes mellitus. Fournal of Clinical Endocrinology and Metabolism $\mathbf{8 2}$ 143-146.

Donner H, Seidl C, Braun J, Siegmund T, Herwig J, Seifried E, Usadel KH \& Badenhoop K 1998 CTLA4 gene can not protect from IDDM in the presence of high-risk HLA DQ8 or DQ2 alleles in German families. Diabetes 47 1158-1160.

Eguchi K 2001 Apoptosis in autoimmune diseases. Internal Medicine $40275-284$.

Einarsdottir E, Soderstrom I, Lofgren-Burstrom A, Haraldsson S, Nilsson-Ardnor S, Penha-Goncalves C, Lind L, Holmgren G, Holmberg M, Asplund K \& Holmberg D 2003 The CTLA4 region as a general autoimmunity factor: an extended pedigree provides evidence for synergy with the $H L A$ locus in the etiology of type 1 diabetes mellitus, Hashimoto's thyroiditis and Graves' disease. European Fournal of Human Genetics 11 81-84.

Faber J, Wiinberg N, Schifter S \& Mehlsen J 2001 Haemodynamic changes following treatment of subclinical and overt hyperthyroidism. European Fournal of Endocrinology 145 391-396.

Farid NR \& Balasz C 1998 The genetics of thyroid associated ophthalmopathy. Thyroid $1998 \mathbf{8} 407-409$.

Fatourechi V 2001 Subclinical thyroid disease. Mayo Clinics Proceedings $76413-416$.

Giorelli M, Livrea P, Defazio G, Ricchiuti F, Pagano E \& Trojano M 2001 IFN- $\beta$ la modulates the expression of CTLA-4 and CD28 splice variants in human mononuclear cells: induction of soluble isoforms. Fournal of Interferon and Cytokine Research $\mathbf{2 1}$ 809-812.

Greene JL, Leytze GM, Emswiler J, Peach R, Bajorath J, Cosand W \& Linsley PS 1996 Covalent dimerization of CD28/CTLA-4 and oligomerization of CD80/CD86 regulate $\mathrm{T}$ cell costimulatory interactions. Fournal of Biological Chemistry 271 26762-26771.

Grenet J, Teitz T, Wei T, Valentine V \& Kidd VJ 1999 Structure and chromosome localization of the human CASP 8 gene. Gene 226 225-232.

Gribben JG, Freeman GJ, Boussiotis VA, Rennert P, Jellis CA, Greenfield E, Barber M, Restivo VA Jr, Ke X, Gray SC \& Nadler LM 1995 CTLA-4 mediates antigen-specific apoptosis of human T cells. PNAS 92 811-815.

Hadj Kacem H, Bellassoued M, Bougacha-Elleuch N, Abid M \& Ayadi H 2001 CTLA-4 gene polymorphisms in Tunisian patients with Graves' disease. Clinical Immunology 101 361-365.

Haimila KE, Partanen JA \& Holopainen PM 2002 Genetic polymorphism of the human ICOS gene. Immunogenetics $\mathbf{5 3}$ $1028-1032$.

Hammond LJ, Palazzo FF, Shattock M, Goode AW \& Mirakian R 2001 Thyrocyte targets and effectors of autoimmunity: a role for death receptors? Thyroid $\mathbf{1 1}$ 919-927.

Harper K, Balzano C, Rouvier E, Mattei MG, Luciani MF \& Golstein P 1991 CTLA-4 and CD28 activated lymphocyte molecules are closely related in both mouse and human as to sequence, message expression, gene structure, and chromosomal location. Fournal of Immunology 147 1037-1044.

Heward JM, Allahabadia A, Carr-Smith J, Daykin J, Cockram CS, Gordon C, Barnett AH, Franklyn JA \& Gough SC 1998 No evidence for allelic association of a human CTLA-4 promoter polymorphism with autoimmune thyroid disease in either population-based case-control or family-based studies. Clinical Endocrinology 49 331-334.

Heward JM, Allahabadia A, Armitage M, Hattersley A, Dodson PM, Macleod K, Carr-Smith J, Daykin J, Daly A, Sheppard MC, Holder RL, Barnett AH, Franklyn JA \& Gough SC 1999 The development of Graves' disease and the CTLA-4 gene on chromosome 2q33. Foumal of Clinical Endocrinology and Metabolism 84 2398-2401.

Huang D, Giscombe R, Zhou Y, Pirskanen R \& Lefvert AK 2000 Dinucleotide repeat expansion in the CTLA-4 gene leads to T cell hyper-reactivity via the CD28 pathway in myasthenia gravis. fournal of Neuroimmunology 105 69-77.

Hueston WJ 2001 Treatment of hypothyroidism. American Family Physician 64 1717-1724.

Hunt PJ, Marshall SE, Weetman AP, Bell JI, Wass JA \& Welsh KI 2000 Cytokine gene polymorphisms in autoimmune thyroid disease. Fournal of Clinical Endocrinology and Metabolism $\mathbf{8 5}$ $1984-1988$

Hutloff A, Dittrich AM, Beier KC, Eljaschewitsch B, Kraft R, Anagnostopoulos I \& Kroczek RA 1999 ICOS is an inducible T-cell co-stimulator structurally and functionally related to CD28. Nature 397 263-266.

Ihara K, Ahmed S, Nakao F, Kinukawa N, Kuromaru R, Matsuura N, Iwata I, Nagafuchi S, Kohno H, Miyako K \& Hara T 2001 Association studies of CTLA-4, CD28, and ICOS gene polymorphisms with type 1 diabetes in the Japanese population. Immunogenetics $\mathbf{5 3}$ 447-454.

Jackson CE \& Puck JM 1999 Autoimmune lymphoproliferative syndrome, a disorder of apoptosis. Current Opinion in Pediatrics 11 $521-527$.

Karandikar NJ, Vanderlungt CL, Walunas TL, Miller SD \& Bluestone JA 1996 CTLA-4: a negative regulator of autoimmune disease. Fournal of Experimental Medicine 184 783-788.

Kopp P 2001 The TSH receptor and its role in thyroid disease. Cellular and Molecular Life Sciences 58 1301-1322.

Kotsa K, Watson PF \& Weetman AP 1997 A CTLA-4 gene polymorphism is associated with both Graves' disease and autoimmune hypothyroidism. Clinical Endocrinology 46 551-554.

Kouki T, Sawai Y, Gardine CA, Fisfalen ME, Alegre ML \& DeGroot LJ 2000 CTLA-4 gene polymorphism at position 49 in exon 1 reduces the inhibitory function of CTLA- 4 and contributes to the pathogenesis of Graves' disease. Fournal of Immunology $\mathbf{1 6 5}$ $6606-6611$

Kouki T, Gardine CA, Yanagawa T \& Degroot LJ 2002 Relation of three polymorphisms of the CTLA-4 gene in patients with Graves' disease. Fournal of Endocrinological Investigation 25 208-213.

Kristiansen OP, Larsen ZM \& Pociot F 2000 CTLA-4 in autoimmune diseases - a common susceptibility gene to autoimmunity? Genes and Immunity 1 170-184.

Lam-Tse WK, Lernmark A \& Drexhage HA 2002 Animal models of endocrine/organ-specific autoimmune diseases: do they really help us to understand human autoimmunity? Springer Seminars in Immunopathology 24 297-321.

Larsen ZM, Kristiansen OP, Mato E, Johannesen J, Puig-Domingo M, de Leiva A, Nerup J \& Pociot F 1999 IDDM12 (CTLA4) on 2q33 and IDDM13 on 2q34 in genetic susceptibility to type 1 diabetes (insulin-dependent). Autoimmunity 31 35-42.

Lazarus JH, Parkes AB \& Premawardhana LD 2002 Postpartum thyroiditis. Autoimmunity 35 169-173.

Lee KM, Chuang E, Griffin M, Khattri R, Hong DK, Zhang W, Straus D, Samelson LE, Thompson CB \& Bluestone JA 1998 
Molecular basis of T cell inactivation by CTLA-4. Science $\mathbf{2 8 2}$ 2263-2266.

Leung HT \& Linsley PS 1994 The CD28 costimulatory pathway. Therapeutic Immunology 1 217-228.

Leung HT, Bradshaw J, Cleaveland JS \& Linsley PS 1995 Cytotoxic T lymphocyte-associated molecule-4, a high-avidity receptor for CD80 and CD86, contains an intracellular localization motif in its cytoplasmic tail. Fournal of Biological Chemistry $27025107-25114$.

Ligers A, Teleshova N, Masterman T, Huang WX \& Hillert J 2001 CTLA-4 gene expression is influenced by promoter and exon 1 polymorphisms. Genes and Immunity 2 145-152.

Lindsten T, Lee KP, Harris ES, Petryniak B, Craighead N, Reynolds PJ, Lombard DB, Freeman GJ, Nadler LM \& Gray GS 1993 Characterization of CTLA-4 structure and expression on human T cells. Foumal of Immunology 151 3489-3499.

Ling V, Wu PW, Finnerty HF, Agostino MJ, Graham JR, Chen S, Jussiff JM, Fisk GJ, Miller CP \& Collins M 2001 Assembly and annotation of human chromosome 2q33 sequence containing the CD28, CTLA4, and ICOS gene cluster: analysis by computational, comparative, and microarray approaches. Genomics 78 155-168.

Linsley PS, Bradshaw J, Greene J, Peach R, Bennett KL \& Mittler RS 1996 Intracellular trafficking of CTLA-4 and focal localization towards sites of TCR engagement. Immunity 4 535-543.

Maalej A, Bougacha N, Rebai A, Bellassouad M, Ayadi-Makni F, Abid M, Jouida J, Makni H \& Ayadi H 2001 Lack of linkage and association between autoimmune thyroid diseases and the CTLA-4 gene in a large Tunisian family. Human Immunology 62 1245-1250.

Magistrelli G, Jeannin P, Herbault N, Benoit De Coignac A, Gauchat JF, Bonnefoy JY \& Delneste Y 1999 A soluble form of CTLA-4 generated by alternative splicing is expressed by nonstimulated human T cells. European Fournal of Immunology 29 3596-3602.

Marron MP, Raffel LJ, Garchon HJ, Jacob CO, Serrano-Rios M, Martinez Larrad MT, Teng WP, Park Y, Zhang ZX, Goldstein DR, Tao YW, Beaurain G, Bach JF, Huang HS, Luo DF, Zeidler A, Rotter JI, Yang MC, Modilevsky T, Maclaren NK \& She JX 1997 Insulin-dependent diabetes mellitus (IDDM) is associated with CTLA4 polymorphisms in multiple ethnic groups. Human Molecular Genetics 6 1275-1282.

Marron MP, Zeidler A, Raffel LJ, Eckenrode SE, Yang JJ, Hopkins DI, Garchon HJ, Jacob CO, Serrano-Rios M, Martinez Larrad MT, Park Y, Bach JF, Rotter JI, Yang MC \& She JX 2000 Genetic and physical mapping of a type 1 diabetes susceptibility gene (IDDM12) to a $100-\mathrm{kb}$ phagemid artificial chromosome clone containing D2S72-CTLA4-D2S105 on chromosome 2q33. Diabetes $49492-499$.

Maurer M, Loserth S, Kolb-Maurer A, Ponath A, Wiese S, Kruse N \& Rieckmann P 2002 A polymorphism in the human cytotoxic T-lymphocyte antigen $4(C T L A 4)$ gene (exon $1+49)$ alters T-cell activation. Immunogenetics 54 1-8.

Najafian N \& Sayegh MH 2000 CTLA4-Ig: a novel immunosuppressive agent. Expert Opinion on Investigational Drugs 9 $2147-2157$

Nistico L, Buzzetti R, Pritchard LE, Van der Auwera B, Giovannini C, Bosi E, Larrad MT, Rios MS, Chow CC, Cockram CS, Jacobs K, Mijovic C, Bain SC, Barnett AH, Vandewalle CL, Schuit F, Gorus FK, Tosi R, Pozzilli P \& Todd JA 1996 The CTLA-4 gene region of chromosome 2q33 is linked to, and associated with, type 1 diabetes. Human Molecular Genetics 5 1075-1080.

Nithiyananthan R, Heward JM, Allahabadia A, Franklyn JA \& Gough SC 2002 Polymorphism of the CTLA-4 gene is associated with autoimmune hypothyroidism in the United Kingdom. Thyroid $123-6$.

Oaks MK \& Hallett KM 2000 Cutting edge: a soluble form of CTLA-4 in patients with autoimmune thyroid disease. Fournal of Immunology 164 5015-5018.
Oaks MK, Hallett KM, Penwell RT, Stauber EC, Warren SJ \& Tector AJ 2000 A native soluble form of CTLA-4. Cellular Immunology 201 144-153.

Ohashi J, Yamamoto S, Tsuchiva N, Hatta Y, Komata T, Matsushita M \& Tokunaga K 2001 Comparison of statistical power between $2 \times 2$ allele frequency and positivity tables in case-control studies of complex disease genes. Annals of Human Genetics 65 197-206.

Oosterwegel MA, Greenwald RJ, Mandelbrot DA, Lorsbach RB \& Sharpe AH 1999 CTLA-4 and T cell activation. Current Opinion in Immunology $11294-300$.

Park YJ, Chung HK, Park DJ, Kim WB, Kim SW, Koh JJ \& Cho BY 2000 Polymorphism in the promoter and exon 1 of the cytotoxic T lymphocyte antigen-4 gene associated with autoimmune thyroid disease in Koreans. Thyroid 10 453-459.

Perez VL, Van Parijs L, Biuckians A, Zheng XX, Strom TB \& Abbas AK 1997 Induction of peripheral T cell tolerance in vivo requires CTLA-4 engagement. Immunity 6 411-417.

Petrone A, Giorgi G, Mesturino CA, Capizzi M, Cascino I, Nistico L, Osborn J, Di Mario U \& Buzzetti R 2001 Association of $D R B 1 * 04-D Q B 1 * 0301$ haplotype and lack of association of two polymorphic sites at CTLA-4 gene with Hashimoto's thyroiditis in an Italian population. Thyroid 11 171-175.

Polymeropoulos MH, Xiao H, Rath DS \& Merril CR 1991 Dinucleotide repeat polymorphism at the human CTLA4 gene. Nucleic Acids Research 194018.

Rapoport B \& McLachlan SM 2001 Thyroid autoimmunity. Fournal of Clinical Investigation $\mathbf{1 0 8}$ 1253-1259.

Riley JL, Blair PJ, Musser JT, Abe R, Tezuka K, Tsuji T \& June CH 2001 ICOS costimulation requires IL-2 and can be prevented by CTLA-4 engagement. Fournal of Immunology 166 4943-4948

Sakai K, Shirasawa S, Ishikawa N, Ito K, Tamai H, Kuma K, Akamizu T, Tanimura M, Furugaki K, Yamamoto K \& Sasazuki T 2001 Identification of susceptibility loci for autoimmune thyroid disease to 5q31-q33 and Hashimoto's thyroiditis to 8q23-q24 by multipoint affected sib-pair linkage analysis in Japanese. Human Molecular Genetics 10 1379-1386.

Sale MM, Akamizu T, Howard TD, Yokota T, Nakao K, Mori T, Iwasaki H, Rich SS, Jennings-Gee JE, Yamada M \& Bowden DW 1997 Association of autoimmune thyroid disease with a microsatellite marker for the thyrotropin receptor gene and CTLA-4 in a Japanese population. Proceedings of the Association of American Physicians 109 453-461.

Shaw G \& Kamen R 1986 A conserved AU sequence from the 3' untranslated region of GM-CSF mRNA mediates selective mRNA degradation. Cell $\mathbf{4 6}$ 659-667.

She JX \& Marron MP 1998 Genetic susceptibility factors in type 1 diabetes: linkage, disequilibrium and functional analyses. Current Opinion in Immunology $\mathbf{1 0} 682-689$.

Shimojo N, Kohno Y, Yamaguchi K, Kikuoka S, Hoshioka A, Niimi H, Hirai A, Tamura Y, Saito Y, Kohn LD \& Tahara K 1996 Induction of Graves-like disease in mice by immunization with fibroblasts transfected with the thyrotropin receptor and a class II molecule. PNAS 93 11074-11079.

Simon SM \& Blobel G 1991 A protein-conducting channel in the endoplasmic reticulum. Cell 65 371-380.

Sprick MR, Rieser E, Stahl H, Grosse-Wilde A, Weigand MA \& Walczak H 2002 Caspase-10 is restricted to and activated at the native TRAIL and CD95 death-inducing signalling complexes in FADD-dependent manner but can not functionally substitute caspase-8. EMBO Fournal 21 4520-4530.

Stagnaro-Green A 2000 Recognizing, understanding, and treating postpartum thyroiditis. Endocrinology and Metabolism Clinics of North America 29 417-430.

Stassi G \& De Maria R 2002 Autoimmune thyroid disease: new models of cell death in autoimmunity. Nature Reviews. Immunology 2 $195-204$. 
Stassi G, Di Liberto D, Todaro M, Zeuner A, Ricci-Vitiani L, Stoppacciaro A, Ruco L, Farina F, Zummo G \& De Maria R 2000 Control of target cell survival in thyroid autoimmunity by $\mathrm{T}$ helper cytokines via regulation of apoptotic proteins. Nature Immunology 1 483-488.

Tivol EA, Borriello F, Schweitzer AN, Lynch WP, Bluestone JA \& Sharpe AH 1995 Loss of CTLA-4 leads to massive lymphoproliferation and fatal multiorgan tissue destruction, revealing a critical negative regulatory role of CTLA-4. Immunity $\mathbf{3}$ 541-547.

Tivol EA, Schweitzer AN \& Sharpe AH 1996 Costimulation and autoimmunity. Current Opinion in Immunology 8 822-830.

Tomer Y 2001 Unraveling the genetic susceptibility to autoimmune thyroid disease: CTLA-4 takes the stage. Thyroid 11 167-169.

Tomer Y \& Davies TF 1997 The genetic susceptibility to Graves' disease. Bailliere's Clinical Endocrinology and Metabolism 199711 431-450.

Tomer Y, Barbesino G, Greenberg DA, Concepcion E \& Davies TF 1999 Mapping the major susceptibility loci for familial Graves' and Hashimoto's diseases: evidence for genetic heterogeneity and gene interactions. Fournal of Clinical Endocrinology and Metabolism 84 $4656-4664$.

Tomer Y, Greenberg DA, Barbesino G, Concepcion E \& Davies TF 2001 CTLA-4 and not CD28 is a susceptibility gene for thyroid autoantibody production. Fournal of Clinical Endocrinology and Metabolism 86 1687-1693.

Tomoyose T, Komiya I, Takara M, Yabiku K, Kinjo Y, Shimajiri Y, Yogi H, Kouki T, Masuda M \& Takasu N 2002 Cytotoxic T-lymphocyte antigen-4 gene polymorphisms and human T-cell lymphotrophic virus-1 infection: their associations with Hashimoto's thyroiditis in Japanese patients. Thyroid 12 673-677.

Tsuchiya N, Ohashi J \& Tokunaga K 2002 Variations in immune response genes and their associations with multifactorial immune disorders. Immunological Reviews 190 169-181.

Vaidya B, Imrie H, Perros P, Dickinson J, McCarthy MI, Kendall-Taylor P \& Pearce SH 1999a Cytotoxic T lymphocyte antigen-4 (CTLA-4) gene polymorphism confers susceptibility to thyroid associated orbitopathy. Lancet 354 743-744.

Vaidya B, Imrie H, Perros P, Young ET, Kelly WF, Carr D, Large DM, Toft AD, McCarthy MI, Kendall-Taylor P \& Pearce SH $1999 b$ The cytotoxic T lymphocyte antigen-4 is a major Graves' disease locus. Human Molecular Genetics 8 1195-1199.

Villanueva R, Inzerillo AM, Tomer Y, Barbesino G, Meltzer M, Concepcion ES, Greenberg DA, MacLaren N, Sun ZS, Zhang DM, Tucci S \& Davies TF 2000 Limited genetic susceptibility to severe Graves' ophthalmopathy: no role for CTLA-4 but evidence for an environmental etiology. Thyroid 10 791-798.

Villanueva R, Tomer Y, Greenberg DA, Mao C, Concepcion ES, Tucci S, Estilo G \& Davies TF 2002 Autoimmune thyroid disease susceptibility loci in a large Chinese family. Clinical Endocrinology $\mathbf{5 6}$ $45-51$.

Wang C \& Crapo LM 1997 The epidemiology of thyroid disease and implications for screening. Endocrinology and Metabolism Clinics of North America 26 189-218.

Waterhouse P, Penninger JM, Timms E, Wakeham A, Shahinian A, Lee KP, Thompson CB, Griesser H \& Mak TW 1995 Lymphoproliferative disorders with early lethality in mice deficient in CTLA-4. Science 270 985-988.

Waterman EA, Watson PF, Lazarus JH, Parkes AB, Darke C \& Weetman AP 1998 A study of the association between a polymorphism in the CTLA-4 gene and postpartum thyroiditis. Clinical Endocrinology 49 251-255.

Weetman AP 2003 Autoimmune thyroid disease: propagation and progression. European Fournal of Endocrinology 148 1-9.

Wiersinga WM \& Bartalena L 2002 Epidemiology and prevention of Graves' ophthalmopathy. Thyroid 12 855-860.

Xu Y, Graves PN, Tomer Y \& Davies TF2002 CTL-4 and autoimmune thyroid disease: lack of influence of the A49 G signal peptide polymorphism on functional recombinant human CTLA-4. Cellular Immunology 215 133-140.

Yanagawa T, Hidaka Y, Guimaraes V, Soliman M \& DeGroot LJ 1995 CTLA-4 gene polymorphism associated with Graves' disease in a Caucasian population. Fournal of Clinical Endocrinology and Metabolism 80 41- 45.

Yanagawa T, Taniyama M, Enomoto S, Gomi K, Maruyama H, Ban Y \& Saruta T 1997 CTLA4 gene polymorphism confers susceptibility to Graves' disease in Japanese. Thyroid 7 843-846.

Yung E, Cheng PS, Fok TF \& Wong GW 2002 CTLA-4 gene A-G polymorphism and childhood Graves' disease. Clinical Endocrinology 56 649-653.

Zaletel K, Krhin B, Gaberscek S, Pirnat E \& Hojker S 2002 The influence of the exon 1 polymorphism of the cytotoxic $\mathrm{T}$ lymphocyte antigen 4 gene on thyroid antibody production in patients with newly diagnosed Graves' disease. Thyroid 12 373-376.

Received in final form 23 March 2003 Accepted 24 March 2003 